the publication concludes with the fourteenth annual report of the Official Seed Testing Station for England and Wales.

\section{Humane Slaughter}

In the thirteenth annual Benjamin Ward Richardson Lecture which was delivered before the Model Abattoir Society on November 27 and has just been published, Sir Leonard Hill, who had chosen for his subject "Electric Methods of Producing Humane Slaughter", maintained that Richardson's aim for humane slaughter was fulfilled by the introduction of the electric stunning instrument, which was a safe process and free from the objections made against shooting. The current is obtained from the usual 200 volt 50 cycle A.c. lighting current, and is reduced to 50 volts by a transformer. The electrodes, which are at the ends of the jaws of a tong-like instrument, are applied for 5 seconds in the case of pigs and for 20 seconds in the case of cattle, after soaking in 20 per cent saline, one on each side of the jaw of pigs, and between the eyes and ears of calves and sheep. The old method of electrocution, which caused violent contractions and even rupture of and hæmorrhage into the muscles, is avoided by this process, and no spilling of blood occurs.

\section{Geographical Methods and Earth Stucture}

The Pontifical Academy of Sciences of the Vatican City announces the offer of a prize of 10,000 lire, to be awarded for an original, unpublished thesis dealing with the utilisation of geophysical methods in the investigation of the interior of the earth. Scientific men of all nationalities are invited to submit theses, five typewritten copies of which, in French, Italian or Latin, should reach the Academy before November 1 of this year. No ordinary member of the Academy, whether resident in Rome or elsewhere, is eligible to compete. The name of an author may be appended to his thesis or, alternatively, the authorship may be indicated by a motto or sign. In the latter event, the name of the author should be enclosed in an envelope marked outside with the motto or sign. A special committee, nominated by the Academy, will judge the theses submitted, and the award will be presented to the successful author at the first meeting of the next session of the Academy, to be held in December.

\section{Fifty Years of Chemical Theory}

The Liversidge Research Lecture delivered before the Australian and New Zealand Association for the Advancement of Science in January by Sir D. Orme Masson dealt with "Crucial Advances in Chemical Theory during the last Half-Century". The lecture gave a brief summary of the initiation of the theory of solution and electrolytic dissociation, the discovery of the inactive elements, $\mathrm{X}$-rays, radioactivity, atomic numbers and the nuclear theory of the atom, isotopes, positive rays and a generalised formula for the structure of all atoms proposed by the lecturer in 1921. The latter states that, if $p$ is a proton, $e$ an electron, $N$ the atomic number and $A$ the true integral mass of the atom, with $n$ (neces- sarily integral) equal to the difference $A-2 N$, then every neutral atom may be represented by the formula $\left[\left(p_{2} e\right)_{N}(p e)_{n}\right] e_{N}$, in which the nucleus is enclosed in the square bracket and the external electronic system is outside it. In the case of hydrogen, $n=-1$. The groups $p e$ and $p_{2} e$ have since been discovered in the neutron and the heavy hydrogen nucleus, respectively.

\section{The Ray Society}

Ar the annual general meeting of the Ray Society on March 20, the following officers were re-elected : President, Sir Sidney Harmer ; Treasurer, Sir David Prain ; Secretary, Dr. W. T. Calman. Prof. F. E. Weiss was elected a vice-president, and Mr. R. Adkin, Dr. Stanley Kemp, and Mr. E. A. Robins were elected new members of Council. In the report of the Council it is announced that the second and final volume of Prof. Stephenson's work on British sea anemones is about to be issued, and it is stated that the publication of this finely illustrated and costly work has been rendered possible by contributions from the Government Grant Fund of the Royal Society, and from several private donors, among whom Mr. J. Spedan Lewis is specially mentioned. It is announced that the issue to subseribers for the current year will be the first volume of a work on British Neuroptera by Mr. F. J. Killington.

\section{Thunderstorm Survey}

Mr. S. Morris Bower, of Langley Terrace, Oakes, Huddersfield, informs us that the annual survey of thunderstorms in the British Isles which he has instituted will be continued during the coming summer. Mr. Bower will be glad to receive details as to the place, date and time of the occurrence of thunder, lightning or hail. Records of damage by lightning will also be especially welcome. The space and time distribution maps of thunder have recently thrown useful light on the question of storm travel, and on its association with meteorological and geographical considerations. The areas of greatest damage by lightning are not necessarily those of maximum storminess, and in view of the value of the determination of such areas in electric power transmission, it is proposed to pay particular attention to this aspect of the survey.

\section{Benefaction for Research into Short-wave Therapy}

THE Medical Research Council has agreed to act as trustee in administering a benefaction of $£ 4,000$ pro: vided by the Stock Exchange Dramatic and Operatic Society and named in honour of the secretary of the Society, Mr. Hugh S. Quekett. The purpose of the gift is the promotion of research into the value of short-wave radiation in the treatment of disease. The money will be used by the Council to meet the cost of assistance and special apparatus in experimental and clinical investigations to be made at the London Hospital under the direction of Prof. D. T. Harris, Dr. E. May, and Sir Robert Stanton Woods.

\section{First Shipment of Petrol from Billingham}

Pending the completion of the erection of the plant for the direct hydrogenation of coal, the first 
shipment of petrol, some 300,000 gallons, produced by the hydrogenation of creosote at the Billingham plant of Imperial Chemical Industries Ltd., has been loaded into the s.s. Otterhound, at Billingham. The petrol is being delivered to the Shell-Mex-B.P. Company which, with the Anglo American Company, are undertaking distribution on behalf of the producers. This delivery initiates regular traffic between Billingham and east coast ports of Great Britain.

\section{Announcements}

Prof. F. G. Donnan, professor of general chemistry in the University of London, has been elected an honorary member of the Chemical Society of Rumania. Prof. Donnan has also been invited by the Danish Natural Science Association to give three lectures in Copenhagen during the week beginning May 20.

His Majesty the King has approved the award of the Royal Medals of the Royal Geographical Society as follows: Founder's Medal to Major R. A. Bagnold, for his journeys in the Libyan Desert; Patron's Medal to Mr. W. Rickmer Rickmers, for his long-continued travels in the Caucasus and Russian Turkistan culminating in his leadership of the AlaiPamir Russo-German Expedition of 1928. The Council has awarded the Victoria Medal to Mr. E. J. Wayland, for his work on the Quaternary geology of Uganda and the Rift, and its relation to man.

The Gold Medal of the Institution of Mining and Metallurgy has been awarded to Mr. Alfred Chester Beatty, in recognition of his distinguished services to the mining industry in the development of mineral deposits, with particular reference to the copper resources of Northern Rhodesia. The following awards have also been made : the Consolidated Gold Fields of South Africa Ltd. Gold Medal to Dr. David Williams, for his geological researches and for his paper on "The Geology of the Rio Tinto Mines, Spain"; the consolidated Gold Fields of South Africa Ltd. Premium of forty guineas to Mr. William Henry Wilson, for his paper on "The Tri-dimensional Projection of Mine Workings" ; the Arthur Claudet Students Prize of ten guineas to Mr. Charles Patrick McMillan, for his paper on "Milling Methods and Costs at the Alaska Mine Flotation Plant of the Southern Rhodesia Base Metals Corporation, Limited, Southern Rhodesia"; the William Frecheville Students Prize of ten guineas to Mr. James G. Traill, for his paper on "The Relation between Width and Cost in Narrow Stopes".

Mr. B. H. St. JohN O'Nerc has been appointed inspector of ancient monuments for Wales. He has been assistant inspector of ancient monuments for Wales since 1930 .

THE following have been elected officers of the Royal Aeronautical Society for 1935-36 : President, Lieut.-Colonel J. T. C. Moore-Brabazon; VicePresident, Mr. H. E. Wimperis ; New Members of Council, Major T. M. Barlow, Major G. P. Bulman, Dr. H. Roxbee Cox, Prof. G. T. R. Hill, Dr. N. A. V.
Piercy; Honorary Treasurer, Major D. H. Kennedy ; Honorary Librarian, Mr. J. E. Hodgson.

THE following appointments have recently been made by the Secretary of State for the Colonies : Mr. F. C. Jessop, to be adviser in animal husbandry, Department of Agriculture, Malta; Mr. J. B. Polding, to be veterinary pathologist, Malta; $\mathrm{Mr}$. R. N. Twisleton-Wykeham Fiennes, to be veterinary officer, Uganda; Mr. H. C. King (late assistant conservator of forests, Ceylon), to be assistant con. servator of forests, Mauritius; Mr. F. B. Wade (senior assistant geologist), to be Government geologist, Department of Lands and Mines, Tanganyika ; Mr. E. B. L. Colborne, to be engineering chemist, Public Works Department, Gold Coast.

IT is probable that the Challenger Society will be making further grants in aid of research during the year 1935-36. The General Committee is prepared to consider applications for small grants in aid of research in marine biology at a recognised laboratory during the current year. Applications, accompanied by details of the proposed research, should reach the Honorary Secretary, Mr. J. R. Norman, British Museum (Natural History), S.W.7, before the end of April.

THE original autograph manuseript of Alcide d'Orbigny's celebrated work "Foraminifères" which formed part of Ramon de la Sagra's "Histoire Physique, Politique et Naturelle de l'Île de Cuba" (Paris, 1839), has been acquired for, and added to, the Heron-Allen Library of Foraminiferal Research at the British Museum (Natural History).

Prof. A. Wolf's work on the beginnings of modern science and technology will be published shortly by Messrs. Allen and Unwin, Ltd., under the title "A History of Science, Technology and Philosophy in the Sixteenth and Seventeenth Centuries". The book is a comprehensive account of one of the most interesting scientific periods in the world's history, and is profusely illustrated from old prints.

Applications are invited for the following appointments, on or before the dates mentioned :-Engineers for the Building Research Station, Garston, and two junior scientific officers at the Road Research Laboratory, Harmondsworth-The Establishment Officer, Department of Scientific and Industrial Research, 16 Old Queen Street, Westminster, S.W.1 (April 17). A teacher of mechanical engineering in the Ipswich School of Engineering - The Secretary for Education, Tower House, Ipswich (April 18). A lecturer in zoology in the University of Capetown-The Secretary to the High Commissioner for the Union of South Africa, Trafalgar Square, London, W.C.2 (April 30). An assistant lecturer in mechanical engineering in the University of Sheffield-The Registrar (May 3). An analyst and demonstrator at the Harper Adams Agricultural College, Newport, Shropshire-The Principal. A director of pathology and Lyle research scholar at Queen Mary's Hospital for the East End, Stratford, E.15-The Secretary. 